\title{
Inequality, abuse of women and duration of breastfeeding, Colombia, 2010: Ecological study
}

\author{
Desigualdad, maltrato de la mujer y duración de la lactancia \\ materna, Colombia, 2010: Estudio ecológico
}

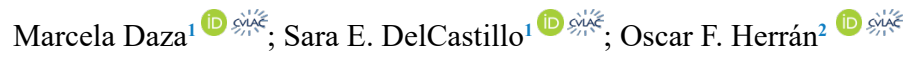 \\ *oscar.herran@gmail.com
}

Forma de citar: Daza D, DelCastillo SE, Herrán OF. Inequality, abuse of women and duration of breastfeeding, Colombia, 2010: Ecological study. Salud UIS. 2022; e22017. doi: https://doi.org/10.18273/saluduis.54.e:22017 (c) (i)

\section{Resumen}

Introducción: la lactancia materna disminuye la morbilidad, la mortalidad y promueve la salud de la madre y del niño. La menor morbilidad en términos relativos en los niños amamantados frente a los no amamantados reduce los costes sanitarios. En Colombia, la duración de la lactancia materna está lejos de los tiempos deseables y sigue disminuyendo. Objetivos: los objetivos fueron (a) determinar la desigualdad económica basada en la pobreza a nivel ecológico durante la lactancia materna exclusiva (LME) y la lactancia materna total (LMT) y (b) establecer los determinantes sociales de la LME y la LMT utilizando el territorio como unidad de análisis. Método: se realizó un estudio ecológico a partir de los datos recogidos en la Encuesta Nacional de Situación Nutricional de 2010 en Colombia sobre la mediana de duración de la lactancia materna exclusiva y la lactancia materna total. Los datos se resumieron en 24 departamentos o unidades geo demográficas que representan el territorio colombiano $(\mathrm{n}=24)$. Catorce variables que representan los niveles de desarrollo económico, social, humano y estructural del territorio se relacionaron mediante regresión lineal para explicar la duración de la LME y la LMT. Resultados: la LME tuvo una duración de 1,18 meses (IC 95 \%: 1,00 a 1,36), y la LMT tuvo una duración de 14,79 meses (IC 95 \%: 13,50 a 16,08). La desigualdad económica fue baja, y el coeficiente de Gini fue de 0,35 para la LME y de 0,10 para la LMT. La duración de la LME se ve afectada por la medida de empoderamiento de género (GEM) $(\beta=-1,94, p=0,006)$ y la cobertura médica $(\%)(\beta=-0,02, p=0,060)$. La duración de la LMT se explica por la pobreza monetaria $(\beta=0,12$, $\mathrm{p}=0,007)$ GEM $(\beta=-9,94, \mathrm{p}=0,033)$ y la tasa de maltrato femenino $x 100000(\beta=0,01, \mathrm{p}=0,005)$. Conclusiones: en Colombia el impacto del desarrollo social y humano es mayor que el aspecto económico como determinante de la LME y de la duración de la LMT. La lactancia materna exclusiva y total son fenómenos que se explican de manera diferente.

Palabras clave: Lactancia; Violencia contra la mujer; Empleo; Seguro médico general; Nivel socioeconómico; Colombia.

\footnotetext{
${ }^{1}$ Universidad Nacional de Colombia. Bogotá, Colombia.

${ }^{2}$ Universidad Industrial de Santander. Bucaramanga, Colombia.
} 


\begin{abstract}
Introduction: Breastfeeding decreases morbidity, mortality and promotes health in the mother and child. The lower morbidity in relative terms in breastfed versus non-breastfed infants reduces healthcare costs. In Colombia, the duration of breastfeeding is far from desirable times and continues to decline. Objectives: The objectives were (a) to determine economic inequality based on poverty at the ecological level during exclusive breastfeeding (EBF) and total breastfeeding (BF) and (b) to establish the social determinants of EBF and BF using the territory as a unit of analysis. Method: An ecological study was conducted based on data collected in the National Survey of the Nutritional Situation of 2010 in Colombia regarding the median duration of exclusive breastfeeding and total breastfeeding. The data was summarized in 24 departments or geodemographic units that represent the Colombian territory $(n=24)$. Fourteen variables representing the economic, social, human and structural development levels in the territory were related by linear regression to explain the duration of EBF and BF. Results: EBF lasted 1.18 months (95\% CI: 1.00 to 1.36), and BF lasted 14.79 months (95\% CI: 13.50 to 16.08). Economic inequality was low, and the Gini coefficient was 0.35 for EBF and 0.10 for BF. The EBF duration is affected by the gender empowerment measure $(\mathrm{GEM})(\beta=-1.94, \mathrm{p}=0.006)$ and medical coverage $(\%)(\beta=-0.02, \mathrm{p}=0.060)$. The $\mathrm{BF}$ duration is explained by the monetary poverty $(\beta=0.12, \mathrm{p}=0.007)$ GEM $(\beta=-9.94, \mathrm{p}=0.033)$ and female abuse rate $\mathrm{x} 100,000(\beta=0.01, \mathrm{p}=0.005)$.

Conclusions: The impact of social and human development is greater than the economic aspect as a determinant of $\mathrm{EBF}$ and BF duration in Colombia. Exclusive and total breastfeeding are phenomena explained differently.
\end{abstract}

Keywords: Breast feeding; Domestic violence; Employment; Insurance; Health; Socioeconomic factors; Colombia.

\section{Introduction}

The benefits of breastfeeding (BF) for the health of mothers and newborns are broad and well known ${ }^{1}$. Breastfeeding affects the future health and well-being of babies, in particular, it has been suggested that exclusive breastfeeding produces metabolic modulation that protects, in the long term, against the development of diabetes, hypertension, obesity, cardio-cerebrovascular disease and other metabolic origin. However, the mechanisms in which it protects are not yet clear ${ }^{2}$. The lower morbidity in relative terms in breastfed versus non-breastfed infants reduces healthcare costs ${ }^{3}$. The beginning and duration of $\mathrm{BF}$ depend on complex individual interactions, biology, culture, and the societies where the mothers live. Multiple variables influence the outcome of BF and the health and nutritional status of mothers and infants ${ }^{4}$. The following variables have been related to the onset and duration of BF: the time between birth and onset ${ }^{4}$, whether the mother and newborn share the same bed or bedroom ${ }^{5}$, the mother's educational level, age, employment status ${ }^{6}$, number of previous children, religion, race, family structure ${ }^{7}$, income level and food security ${ }^{8}$, urban development, social support of the parents, family, and health services, housing tenure, beliefs, supply and access to dairy formulas and substitutes, the characteristics of employment and the work environment and, demographic and epidemiological profiles".
BF inequality has been established at the individual level between races and socioeconomic statuses ${ }^{7}$, but given the complex interaction between variables and the conditions of $\mathrm{BF}$ in each culture and territory, eg. Socioeconomic level, inequality, prevalence and duration, the results cannot be extrapolated ${ }^{10}$. The geographic territory is of special interest in ecological studies. In the territory (landscape), epidemiology has managed to establish that it is where all the variables interact to produce potentiated effects, for example, the characteristics of the neighborhood can impact on survival from colon cancer ${ }^{11}$. The characteristics of the territory are the result at the same time condition the economic, social and physical conditions in which people live. That is, the bidirectional relationship between the characteristics of the territory and the social and economic organization of the subjects produces the environment or "reality" in which they live $e^{11,12}$. Colombia is divided into 34 geographic territories, these are called "departments" and in this study they will be called geographic demographic units. In Colombia, the study of economic inequality regarding nutritional variables has shown that the underlying principle in the concept of inequality, "the poor are in a worse condition than the less poor or the rich", has been questioned ${ }^{13}$. In Colombia, the average duration of $\mathrm{BF}$ is 14.9 months and that of exclusive breastfeeding (EBF) is 1.8 months ${ }^{14}$. The current study provides data on economic inequality and social determinants at an ecological 
level, where the analysis of variables such as territory (departments or geographic demographic units) and poverty are related to BF. In addition, it challenges the concepts of integral development, equality of rights and the opportunities of women versus men and reinforces the gender approach in the work environment.

Colombia is one of the most violent countries in the world, the expressions of violence are associated with the armed conflict, the "macho" culture, intolerance, poverty and many others. Women in all cases are victims and violence generated by the partner occupies a prominent place in the statistics. According to the Observatory on Violence Against Women, violence in different forms against women is present in $79 \%$ of households ${ }^{15,16}$. There is little information about the effect of physical or psychological abuse by the partner towards the woman who breastfeeds. In developed societies such as Andalusia-Spain, women with psychological abuse avoid breastfeeding ${ }^{17}$. The empowerment of women and their ability to avoid or resist abuse is theoretical and we do not know how empowerment is related to violence when it breastfeeds. The objectives were a) to determine economic inequality based on monetary poverty at the ecological level in the duration of EBF - Up to 6 months- and BF - Up to 36 months- and $b$ ) to establish the social determinants of $\mathrm{EBF}$ and BF using geodemographic units of Colombia (also known as departments) as a unit of analysis.

\section{Methods}

This was an ecological study carried out using data collected by the 2010 Colombian National Survey of Nutritional Status (Encuesta Nacional de la Situación Nutricional de Colombia- ENSIN-2010) and other secondary data sources collected in 2009-2012 during the same period in which ENSIN-2010 was conducted ${ }^{14}$. The unit of analysis was the geodemographic units of Colombia. BF data such as the development index, statistics of economic and environmental variables are stable over time. The above allows the study of these associations in ecological studies with data that is not necessarily concurrent.

\section{Universe and sample}

The universe consisted of the 33 geodemographic units of Colombia. The sample comprised 24 of these units, those that included data on monetary poverty ${ }^{18}$. These 24 geodemographic units represent $100 \%$ of those with available data, $72.7 \%$ of the universe and at least $90 \%$ of the Colombian population inhabit them. With the data of interest for this study, from the surveys and the various official sources, a database was created. Each geodemographic unit was a row in the database and the data of the variables of interest were the columns; one column for each variable.

\section{Data sources}

Data sources included the ENSIN-2010 and its final published report $^{14}$, a previous ecologic study on inequalities in nutritional variables ${ }^{13}$, the National Administrative Department of Statistics (Departamento Administrativo Nacional de Estadística- DANE), the United Nations Development Program (UNDP) and the Colombian Ministry of Health and Social Protection (Ministerio de Salud y Protección Social de Colombia-MinSalud). The details of the information used are described below. The information related to the variables presented below was summarized for each geodemographic unit in the most appropriate way as the proportion (\%), the mean, or, for the $\mathrm{BF}$, the median.

\section{Study variables}

The two output or dependent variables were the median duration (in months) of EBF and BF. The data were obtained through direct interviews from a representative sample of 9,389 mothers with children under 36 months that were included in ENSIN-2010 ${ }^{14}$ and was summarized in 24 geodemographic units. The construction of the breastfeeding variables was done in a "compositional" way, starting from individual data and summarized in a population variable ${ }^{19}$. The information used was reported in the official report of the ENSIN-2010 ${ }^{14}$.

Exclusive breastfeeding (EBF) and total breastfeeding (BF). The median duration of breastfeeding among children less than 6 months of age and children less than 36 months respectively. ENSIN-2010.

According to World Health Organization (WHO), EBF is defined as “... infants receive only breast milk and may or may not include oral rehydration or vitamin and mineral drops or medicines". BF includes EBF, predominant breastfeeding and breastfeeding plus family feeding or complementary feeding ${ }^{14}$. Sixteen additional variables were studied for each of the 24 geodemographic units of interest using data from the same period or near to that of the ENSIN-2010 report. 
Total childbearing age population - 2009

This was a projection based on the 2005 national census regarding the number of women between 15 and 49 years old within the geodemographic unit ${ }^{20}$.

\section{Total number of births - 2010}

The number of certified births was obtained from DANE within the geodemographic unit ${ }^{21}$.

\section{Monetary poverty - year 2011(\%)}

This was obtained from household monetary income. DANE has used the same methodology since 2011 and reports this index regularly. The data was obtained from regional bulletins, one per geodemographic unit ${ }^{17}$. The data is also available in a publication regarding the study of inequality using nutritional variables in Colombia ${ }^{13}$. Monetary poverty is an indirect measure that is constructed based on the measurement of the current per capita income of the household, divided by the total of its members; and it compares with the monetary cost of acquiring a food basket. For example, if the per capita income needed to buy the food basket is $\$ 250,000$ pesos in a 4-member household and an income of $\$ 10,000,000(4 * 250,000)$ is not reached, the household is declared as poor.

\section{Gini coefficient - 2011}

This measure represents the income inequality in each geodemographic unit; it is measured on a regular basis by $\mathrm{DANE}^{22}$. Gini takes values between 0 and 1 , where 0 represents perfect equality. The closer to 1 , the greater the distribution inequality is ${ }^{23}$.

\section{Lack of postpartum counseling during breastfeeding- based on ENSIN-2010 (\%)}

This was the percentage of women that did not have counseling from healthcare professionals on how to start BF at the time of childbirth or at 48 hours postpartum during their stay in a healthcare institution. ENSIN-2010 - direct survey of women with children up to five years of age ${ }^{13,14}$. The WHO and UNICEF in the eighties made a joint declaration for the Promotion, Protection and Support of Natural BF, in which they propose ten steps to a happy BF: one of these steps is to start BF during the hour after delivery. In Colombia, the 2010-2020 Maternal Breastfeeding Plan proposes as a specific action: advice for the implementation of successful BF in the first 48 hours postpartum. All personnel of health institutions in Colombia have the obligation to participate in the implementation and development of this Ten-Year Plan ${ }^{13,14}$.
Household food insecurity - based on ENSIN-2010 (\%)

ENSIN-2010 estimated household food insecurity (HFI) through the Latin American and Caribbean Food Security Scale (ELCSA) ${ }^{14}$. The survey was answered by the head of the household. ELCSA evaluates a dimension of HFI, which is physical access to food. The cutoff point for declaring HFI varies depending on the existence of minors, allowing it to be established in three levels: mild, moderate and severe. ENSIN-2010 officially defines it as "the limited or uncertain availability of adequate and safe nutritional foods, or the limited and uncertain capacity to acquire adequate food in socially acceptable ways" ${ }^{\prime 3,14}$.

Annual growth rate, in volume of the gross domestic product (GDP) for geodemographic units (\%) - 2011

This measure represents growth in the total value of goods and services produced in the geodemographic unit, i.e., the variation of the total production of each final good or service using economic resources at a common market price. The 2011 GDP by department unit was used ${ }^{18}[50]$. These results are based on the UN System of National Accounts (SNA 1993 and 2008) and on the 2005 DANE methodology for national accounts $^{24}$. In 2011, Colombia reported a GDP growth of $6.6 \%$, mainly based on mining and quarrying activities $(14.5 \%)$ and construction $(8.2 \%)^{24}$.

\section{Human development index (HDI) - 2011}

This is a summary measure of the average achievement within the geodemographic unit. It considers three key dimensions of human development: a) a long and healthy life, b) being knowledgeable/having access to education, and c) having a decent standard of living. The HDI is the arithmetic mean of normalized indices of each of the three dimensions. The health dimension is assessed by life expectancy at birth; the education dimension is measured by average years of schooling for adults aged 25 years or older and by the gap between the real and expected years of schooling for children of school age; and the standard of living dimension is measured by gross national income per capita. This index is calculated and reported on a regular basis by the United Nations Program for Development UNPD ${ }^{25}$. The HDI index provides values between 0 and 1 , with 0 being the lowest and 1 the highest. 


\section{Gender empowerment measure - 2009 (GEM)}

This indicator is reported by the UNDP. It measures the level of opportunity of women in three areas: a) political participation and decision-making at government levels; b) economic participation and decision-making - the proximal participation of women in the economic and work environment-evaluating the relative participation of men in technical and professional positions; and c) power over economic resources, based on estimated earned income versus males ${ }^{25}$. In summary, this index measures gender inequality in key aspects of economic and political participation, as well as the capacity of individual self-management through individual decision making. GEM takes values between 0 and 1 , with 1 being the highest possible level of equality versus men.

\section{Female illiteracy rate - $2011(\%)$}

This is the ratio between women who declared an inability to read or write and the total number of women who answered this question in the Great Integrated Household Survey (Gran Encuesta Integrada de Hogares- GEIH) conducted by DANE ${ }^{26}$.

\section{Maximum schooling for women aged 15-49 years - 2011.}

This is the average number of maximum school years reached for women between the ages of 15 and 49 years in each of the nine typologies into which Colombian households are classified according to the $\mathrm{GEIH}^{26}$.

\section{Total cases of domestic female abuse - 2012}

This is the total number of cases where women were abused by family members. Includes all types of abuse; Physical, psychological, sexual, symbolic and economic performed by the couple or a family member. The data were reported by the Colombian Institute of Legal Medicine (Instituto Colombiano de Medicina Legal) ${ }^{27}$.

\section{Female abuse rate $x$ 100,000 - 2012}

This is the proportion between the number of cases of family violence -by the couple- where a woman was the victim, reported by the Colombian Institute of Legal Medicine $^{27}$, divided by the total number of women of childbearing age, estimated by DANE based on the 2005 census for the same period and geodemographic unit ${ }^{20}$.

\section{Maternal mortality rate $x$ 100,000 - 2010}

This is the ratio between the total number of female deaths related to pregnancy or its management, excluding accidental or incidental deaths, and the total number of living newborns estimated by DANE in the same period and geodemographic unit ${ }^{28}$.

\section{Medical coverage (\%) - 2010}

This was based on the number of affiliates provided by the Single Database of Affiliates, in contributory and subsidized regimes, as of December 31 of each year. The data were reported by MinSalud and were compared to population estimations according to DANE, based on the 2005 census $^{20}$.

\section{Inequality}

Twenty-two inequality indices based on monetary poverty were calculated. The study of economic inequality requires the calculation of various indices, as no index is superior to another ${ }^{13,23}$.

\section{Data processing and statistical analysis}

The normal distribution of EBF and BF was verified by the Shapiro-Francia test. Based on the statistical normality test, EBF was transformed (square root EBF). The analysis consisted of four phases: a) the description of the context variables, b) establish economic inequality indices based on ranges, disparity or dispersion, disproportionality and concentration in regression models and those based on the concept of entropy $^{23}, \mathrm{c}$ ) establish the bivariate relationship of each of the two dependent variables with the explanatory variables. For this, linear regression (LR) models with $\mathrm{EBF}$ or BF were used as dependent variables, and the explanatory variables were each of the 16 variables of interest. The results were reported as partial regression coefficients $(\beta)$ with their respective $95 \%$ confidence intervals $(95 \% \mathrm{CI})$ and $\mathrm{p}$ values. Finally, d) multivariate LR models were carried out for each dependent variable. Since some of the variables of interest theoretically have overlapping domains, before using them in multivariate models, we discard the collinearity between them. The selection of candidate variables for the models was based on the value of $p$ achieved in bivariate exploration, with $p<0.30$. In addition to the $\beta$, the t-value statistic, the statistical significance of each variable, the model constant and goodness-of-fit of the model $\left(\mathrm{r}^{2}\right)$ were reported. The criteria for establishing several models (A-F) was the search for parsimony, that is a better explanation with the least number of variables. The inequality indices were estimated using Epidat $^{29}$ and Stata ${ }^{30}$ for the LR models. 


\section{Ethics and consent}

Each analysis was conducted under the principles of the Helsinki declaration. The sources used are public and are therefore unidentified. This study is classified as "riskfree" according to resolution 8430 of 1993, MinSalud, Colombia. The medical research ethics committee of the National University of Colombia (Universidad Nacional de Colombia) approved all procedures.

\section{Results}

The median duration was 1.18 months (95\% CI: 1.00 to 1.36 ) for EBF and 14.79 months (95\% CI 13.50 to 16.08 ) for BF. The mean monetary poverty was $41.54 \%$ (95\% CI: 35.70 to 47.38 ), with a minimum of $13.1 \%$ and a maximum of $64.0 \%$. The mean GEM was 0.71 (95\% CI: 0.66 to 0.75 ), with a minimum of 0.50 and a maximum of 0.89 . The mean medical coverage was $88.2 \%$ (95\% CI: 85.4 to 90.9 ), with a minimum of $73.7 \%$ and a maximum of $100 \%$. The description of the variables is presented in Table 1.

\section{Inequality}

Inequalities are systematically greater in every index calculated for EBF (Table 2). However, dispersion is greater in the median duration for BF. Based on the range of indices, it was established that if monetary poverty in Colombia were reduced to the minimum levels, $13 \%$, the median duration of EBF would increase by an average of $57 \%$ (an increase of 20 days), and that of BF would increase by an average of $10 \%$ (an increase of 42 days).
Based on the Gini coefficient, inequality exists for $\mathrm{EBF}$ and is negligible or nonexistent for BF. The concentration index also confirms this and shows that the trend in the relationship between the duration of $\mathrm{BF}$ and monetary poverty is not necessarily linear, with longer or shorter durations in the intermediate geodemographic units according to the monetary poverty compared to peripheral geodemographic units. The indices based on regression models no longer show inequalities in absolute terms, such as those based on ranges, but rather in relative terms against a theoretical referent based on Ridit and are greater than the ratio of extreme rates, reconfirming the greatest dispersion in BF. Inequality based on the concept of entropy is consistent with the previous indices, the greater inequality in $\mathrm{EBF}$ in relative terms compared to $\mathrm{BF}$, and the greater entropy in BF. Based on these results, the theoretical potential for redistribution of EBF is up to $20 \%$ and of $\mathrm{BF}$ is close to $0 \%$. The values of each inequality index are presented in Table 2.

\section{Association of contextual variables with EBF and $B F$}

Two variables were associated with EBF, both in an inverse way: postpartum counseling (partial regression coefficient, $\beta=-0.02$ (95\% CI: -0.04 to $>-0.001), \mathrm{p}=0.033$ and GEM, $\beta=-1.97$ (95\% CI: -3.33 to -0.55 ), $\mathrm{p}=0.009$. Regarding BF, GEM (inverse association) $\beta=-13.23$ (95\% CI: -23.68 to -2.77 ), $\mathrm{p}=0.016$. Table 3 shows the partial regression coefficients, $95 \%$ CIs and $\mathrm{p}$ values for all of the studied bivariate relationships.

Table 1. Characteristics of the study population.

\begin{tabular}{|c|c|c|c|}
\hline Variable & Unit of measurement & Value & SD \\
\hline Exclusive breastfeeding ${ }^{a}$ & Median-Months & 1.18 & 0.42 \\
\hline Total breastfeeding ${ }^{b}$ & Median-Months & 14.79 & 3.04 \\
\hline Total childbearing age population & Number & 486482 & 478082 \\
\hline Total number of births & Number & 26446 & 25805 \\
\hline Monetary poverty & Percentage $(\%)$ & 41.54 & \\
\hline Gini coefficient & Mean: Range: 0 to 1 & 0.52 & 0.03 \\
\hline Lack of postpartum counseling ${ }^{c}$ & Prevalence $(\%)$ & 33.88 & \\
\hline Household food insecurity ${ }^{d}$ & Prevalence $(\%)$ & 48.64 & \\
\hline Annual growth rate & Percentage (\%) & 5.97 & \\
\hline Human development index & Mean: Range: 0 to 1 & 0.81 & 0.05 \\
\hline Gender empowerment measure & Number: Range: 0 to 1 & 0.71 & 0.11 \\
\hline Female illiteracy rate & Prevalence $(\%)$ & 23.60 & \\
\hline Maximum schooling for women aged $15-49$ years & Mean: Number & 9.09 & 0.73 \\
\hline Female abuse $^{\mathrm{e}}$ & rate $\mathrm{x} 100,000$ & 384.65 & 152.48 \\
\hline Maternal mortality ${ }^{\mathrm{f}}$ & rate $\mathrm{x} 100,000$ & 90.11 & 47.27 \\
\hline Medical coverage & Percentage $(\%)$ & 88.16 & 6.59 \\
\hline
\end{tabular}

${ }^{\mathrm{a}}$ Among children less than 6 months of age. ${ }^{\mathrm{b}}$ Among children less than 36 months of age. ${ }^{\mathrm{c}}$ In women with children up to five years old. ${ }^{\mathrm{d}}$ Based on the Latin American and Caribbean Scale of Food Security (ELCSA). ${ }^{\mathrm{e}}$ Defined as [Total cases of violence against women by the couple / total of women of childbearing age]. ${ }^{\mathrm{f}}$ Defined as [Total maternal deaths / total live births]. 
Table 2. Indexes of inequality in duration (Months) of exclusive breastfeeding and total breastfeeding, based on monetary poverty. Colombia, 2010.

\begin{tabular}{|c|c|c|}
\hline $\begin{array}{l}\text { Ordered by the economic variable } \\
\text { Sense of the economic variable: Negative } \\
\text { Sense of the lactation variables: Positive }\end{array}$ & Exclusive breastfeeding (EBF) ${ }^{\text {a }}$ & $\begin{array}{c}\text { Total breastfeeding } \\
(\mathrm{BF})^{\mathrm{a}}\end{array}$ \\
\hline \multicolumn{3}{|c|}{ Rank-based } \\
\hline Reason for extreme rates & 0.27 & 0.86 \\
\hline Difference of extreme rates & -1.90 & -2.20 \\
\hline Population Attributable Risk & -0.94 & -1.39 \\
\hline Population Attributable Risk (\%) & -57.05 & -9.45 \\
\hline \multicolumn{3}{|c|}{ Based on disparity or dispersion } \\
\hline Pearcy-Keppel & 2.12 & 0.51 \\
\hline Pearcy-Keppel (Adjusted & 1.16 & 4.91 \\
\hline Variance between groups & 1.13 & 6.83 \\
\hline \multirow{2}{*}{\multicolumn{3}{|c|}{ Based on disproportionality and concentration }} \\
\hline & & \\
\hline Gini & 0.35 & 0.10 \\
\hline Concentration & 0.11 & -0.01 \\
\hline \multicolumn{3}{|c|}{ Based on regression models } \\
\hline Effect index & -0.02 & 0.01 \\
\hline Coefficient of determination & 0.11 & 0.00 \\
\hline Inequality of the slope & 1.01 & -0.55 \\
\hline Inequality of Pamuk & 0.66 & 0.04 \\
\hline Inequality of Kunst and Mackenbach & 1.50 & 1.04 \\
\hline Bounded inequality & 0.53 & 1.03 \\
\hline \multicolumn{3}{|c|}{ Based on the concept of Entropy } \\
\hline Kullback-Liebler (Z) & 0.19 & 0.02 \\
\hline Hoover or dissimilarities $(\mathrm{Z})$ & 0.24 & 0.07 \\
\hline Theil $(Z)$ & 0.18 & 0.02 \\
\hline Kullback-Liebler (Equivalent) ${ }^{\mathrm{b}}$ & 0.34 & 0.46 \\
\hline Hoover or dissimilarities (Equivalent) ${ }^{b}$ & 0.32 & 0.41 \\
\hline Theil (Equivalent) ${ }^{\mathrm{b}}$ & 0.35 & 0.46 \\
\hline
\end{tabular}

${ }^{\mathrm{a}}$ Based on the median. ${ }^{\mathrm{b}}$ Entropy equivalence.

Table 3. Association between the duration (months) of exclusive breastfeeding, total breastfeeding and the contextual variables of the geodemographic unit. Colombia, 2010.

\begin{tabular}{|c|c|c|c|c|}
\hline \multirow{2}{*}{ Variable } & \multicolumn{2}{|c|}{$\begin{array}{c}\text { Exclusive breastfeeding } \\
(\text { EBF })^{a}\end{array}$} & \multicolumn{2}{|c|}{$\begin{array}{l}\text { Total breastfeeding } \\
\text { (BF) }\end{array}$} \\
\hline & $\beta(95 \% \mathrm{CI})^{b}$ & P-Value ; $(\mathrm{t} \text { Value })^{\mathrm{c}}$ & $\beta(95 \% \mathrm{CI})^{\mathrm{b}}$ & $\begin{array}{l}\text { P-Value : (t } \\
\text { Value) }{ }^{c}\end{array}$ \\
\hline Exclusive breastfeeding - (Months) & & & $1.16(0.10,2.24)$ & $0.034(2.26)$ \\
\hline Total breastfeeding - (Months) & $0.05(-0.00,0.11)$ & $0.056(2.02)$ & & \\
\hline Total childbearing age population & $-0.00(-0.00,0.00)$ & $0.718(0.37)$ & $0.00(-0.00,0.00)$ & $0.766(-0.30)$ \\
\hline Total number of births & $-0.00(-0.00,0.00)$ & $0.622(0.50)$ & $-0.00(-0.00,0.00)$ & $0.899(-0.13)$ \\
\hline Monetary poverty $(\%)$ & $-0.01(-0.02,0.01)$ & $0.234(-1.22)$ & $0.04(-0.04,0.14)$ & $0.381(0.89)$ \\
\hline Gini coefficient & $1.43(-4.30,7.17)$ & $0.609(0.52)$ & $23.3(-17.05,63.67)$ & $0.244(1.20)$ \\
\hline Lack of postpartum counseling $(\%)^{d}$ & $-0.02(-0.04,-0.00)$ & $0.033(-2.27)$ & $0.01(-0.13,0.15)$ & $0.904(-0.12)$ \\
\hline Household food insecurity (\%) ${ }^{\mathrm{e}}$ & $-0.01(-0.03,0.00)$ & $0.133(-1.56)$ & $0.03(-0.09,0.14)$ & $0.636(0.48)$ \\
\hline Annual growth rate $(\%)$ & $0.01(-0.04,0.05)$ & $0.749(0.32)$ & $0.20(-0.08,0.49)$ & $0.157(1.47)$ \\
\hline Human development index & $2.56(-1.00,6.10)$ & $0.148(1.50)$ & $-8.08(-34.66,18.50)$ & $0.535(-0.63)$ \\
\hline Gender empowerment measure & $-1.97(-3.38,-0.55)$ & $0.009(-2.89)$ & $-13.2(-23.68,-2.77)$ & $0.016(-2.62)$ \\
\hline Female illiteracy rate $(\%)$ & $-0.01(-0.04,0.02)$ & $0.500(-0.69)$ & $0.11(-0.13,0.35)$ & $0.350(0.95)$ \\
\hline Maximum schooling for women $15-49 y$ & $0.06(-0.19,0.31)$ & $0.615(0.51)$ & $-0.86(-2.66,0.93)$ & $0.329(-1.0)$ \\
\hline Total cases of domestic female abuse & $0.00(-0.00,0.00)$ & $0.539(0.62)$ & $0.00(-0.00,0.00)$ & $0.780(0.28)$ \\
\hline Female abuse rate $\times 100,000^{f}$ & $0.00(-0.00,0.00)$ & $0.190(1.35)$ & $0.01(-0.00,0.02)$ & $0.056(2.02)$ \\
\hline Maternal mortality rate $\mathrm{x} 100,000^{\mathrm{g}}$ & $-0.00(-0.01,0.00)$ & $0.075(-1.87)$ & $0.01(-0.02,0.04)$ & $0.556(0.60)$ \\
\hline Medical coverage $(\%)$ & $-0.02(-0.05,0.00)$ & $0.094(-1.75)$ & $-0.01(-0.22,0.19)$ & $0.883(-0.15)$ \\
\hline \multicolumn{5}{|c|}{$\begin{array}{l}\text { a Based on the square root of the EBF. }{ }^{\mathrm{b}} \beta \text { Partial regression coefficient and its } 95 \% \text { confidence interval, reached in a simple } \\
\text { linear regression model with EBF or BF (months) as the dependent variable and the covariate of interest as the only explanatory } \\
\text { one. }{ }^{\mathrm{c}} \text { ( Student's t statistic). }{ }^{\mathrm{d}} \text { In women with children up to five years old. }{ }^{\mathrm{e}} \text { Based on the Latin American and Caribbean Scale } \\
\text { of Food Security (ELCSA). }{ }^{\mathrm{f}} \text { Defined as [Total cases of violence against women by the couple / total of women of childbearing } \\
\text { age]. }{ }^{\mathrm{g}} \text { Defined as [Total maternal deaths / total live births]. }\end{array}$} \\
\hline
\end{tabular}


Table 4. Linear regression models that explain the duration (months) of exclusive and total breastfeeding in Colombia, 2010.

\begin{tabular}{|c|c|c|c|}
\hline \multirow{2}{*}{$\begin{array}{c}\text { Variable } \\
\text { Exclusive breastfeeding (EBF) }{ }^{a}\end{array}$} & \multicolumn{3}{|c|}{ Model } \\
\hline & & & \\
\hline & $\mathbf{A}$ & B & $\mathbf{C}$ \\
\hline Monetary poverty & $0.01(0.96)^{b}$ & & \\
\hline Lack of postpartum counseling ${ }^{c}$ & $0.00(0.13)$ & & \\
\hline Household food insecurity (\%) d & $-0.00(-0.28)$ & & \\
\hline Human development index & $5.73(1.30)$ & $1.65(1.14)$ & \\
\hline Gender empowerment measure & $-1.38(-1.62)$ & $-1.79(-2.77)^{* * \mathrm{e}}$ & $-1.94(-3.03)^{* * *}$ \\
\hline Female illiteracy rate $(\%)$ & $0.03(0.83)$ & & \\
\hline Female abuse rate $\times 100,000^{f}$ & $-0.00(-0.32)$ & & \\
\hline Medical coverage $(\%)$ & $-0.03(-1.90)^{*}$ & $-0.02(-1.96)^{*}$ & $-0.02(-1.99)^{*}$ \\
\hline Maternal mortality rate $\mathrm{x} 100,000^{\mathrm{g}}$ & $-0.00(-0.69)$ & & \\
\hline $\mathrm{R}^{2}$ (Goodness of fit) & 0.51 & 0.43 & 0.39 \\
\hline $\mathrm{R}^{2}$ Adjusted & 0.19 & 0.34 & 0.33 \\
\hline Intercept & 0.08 & 2.98 & 4.46 \\
\hline $\mathrm{n}$ & 24 & 24 & 24 \\
\hline \multicolumn{4}{|l|}{ Total breastfeeding (BF) } \\
\hline & D & $\mathbf{E}$ & $\mathbf{F}$ \\
\hline Exclusive breastfeeding & $0.80(1.55)$ & $0.76(1.53)$ & \\
\hline Monetary poverty & $0.13(2.66)^{* *}$ & $0.13(3.32)^{* * *}$ & $0.12(3.02)^{* * *}$ \\
\hline Gini coefficient & $2.13(0.11)$ & & \\
\hline Annual growth rate $(\%)$ & $0.10(0.81)$ & & \\
\hline Gender empowerment measure & $-5.09(-0.94)$ & $-5.94(-1.20)^{* *}$ & $-9.94(-2.29) * *$ \\
\hline Female abuse rate $\mathrm{x} 100,000 \mathrm{f}$ & $0.01(2.63)^{* *}$ & $3.19(2.54)^{* * *}$ & $0.01(3.18)^{* * *}$ \\
\hline $\mathrm{R}^{2}$ (Goodness of fit) & 0.60 & 0.58 & 0.53 \\
\hline $\mathrm{R}^{2}$ Adjusted & 0.45 & 0.49 & 0.46 \\
\hline Intercept & 5.83 & 7.65 & 11.92 \\
\hline $\mathrm{n}$ & 24 & 24 & 24 \\
\hline
\end{tabular}

${ }^{a}$ Based on the square root of the EBF. ${ }^{b} \beta$ and value of the statistic (t) in parentheses. ${ }^{\mathrm{c}}$ In women with children up to five years old. ${ }^{\mathrm{d}}$ Based on the Latin American and Caribbean Scale of Food Security (ELCSA). e *, **,*** represent the statistical significance of $10 \%, 5 \%$ and $1 \%$ respectively. ${ }^{f}$ Defined as [Total cases of violence against women by the couple / total of women of childbearing age]. ${ }^{g}$ Defined as [Total maternal deaths / total live births].
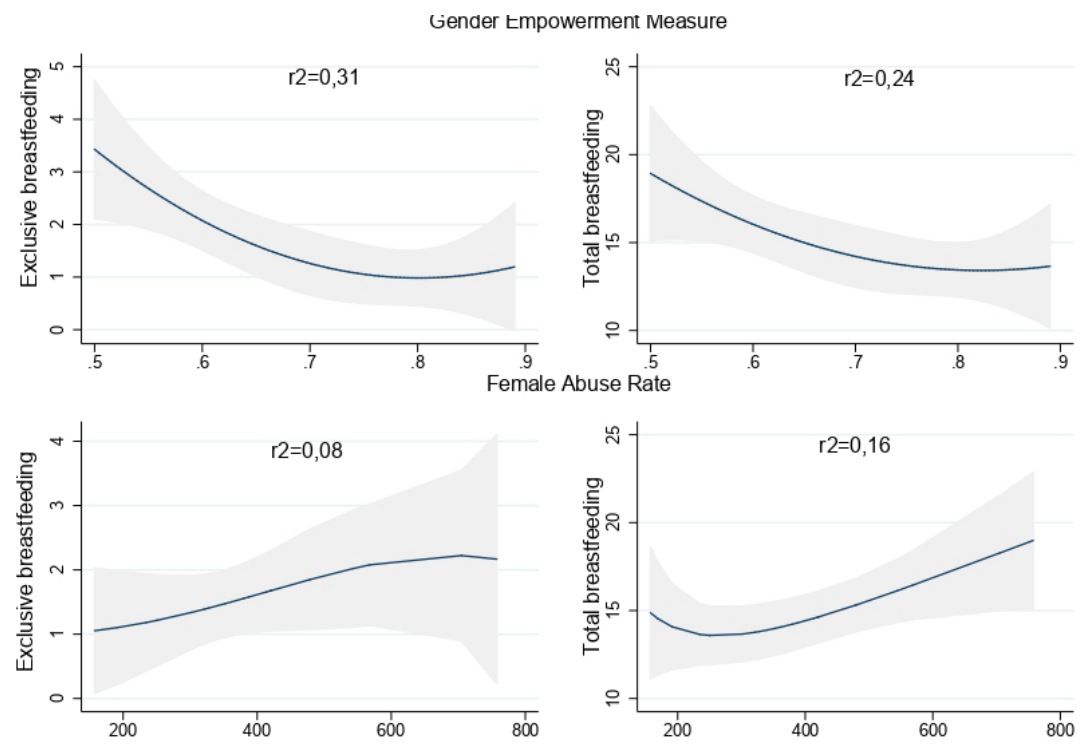

Based on linear regression. The shaded area is $95 \% \mathrm{Cl}$.

Figure 1. Relationship between the Gender Empowerment Measure (GEM), the Female Abuse Rate (FAR) and the median duration (months) of exclusive breastfeeding and Total, Colombia 2010. The GEM takes values between 0 and 1 ; the value of 1 represents the greatest equality with men. The FAR was calculated as; [Number of cases of abuse towards women / Total of women of childbearing age] x 100.000. $\mathrm{r} 2$ is the coefficient of determination in the linear regression model. 


\section{Models explaining EBF and BF}

The A-E linear regression models show plausible explanations at an ecological level for EBF and BF (Table 4). Between 39\% (model C) and 53\% (model A) of the EBF duration can be explained by contextual variables in the geodemographic units. Between $53 \%$ (model F) and 60\% (model D) of the BF duration can be explained by contextual variables in the geodemographic units. The most important variables for the EBF median duration are GEM and the percentage of medical coverage (in an inverse relation). The most determinant variables for the BF duration are GEM (inversely), the rate of female abuse (directly), and monetary poverty (directly). Figure 1 shows the unadjusted relationships of GEM and the rate of female abuse with EBF and BF.

\section{Discussion}

$\mathrm{EBF}$ and $\mathrm{BF}$ are phenomena explained differently. There is no economic inequality in the duration of EBF and $\mathrm{BF}$. However, care must be taken when interpreting the above statement and all those made in this discussion for various aspects; a) the median duration of exclusive and total breastfeeding is far from a desirable minimum in all the territories studied, b) all the inequality indices are methodologically product at most of bivariate analyzes, c) the same set of values in the indices inequality can be interpreted differently, here it is important to state that there is no perfect equality and that, for example, in developed societies such as Switzerland and Canada, which are examples of equality, the Gini coefficient for 2010 was 29.1 and 33.6 respectively ${ }^{31}$. The territories where women participate more in politics, and in general in development activities that look for equality with men, are inversely related to the duration of the BF. A relevant and novel finding is that in the territories where there is greater abuse towards women, the abuse was directly related to the duration of the $\mathrm{BF}$, explained as a hypothesis, by affective compensation of women with their children. The impact of social and human development is greater than the economic aspect as a determinant of EBF and $\mathrm{BF}$ duration in Colombia. Models $\mathrm{C}$ and $\mathrm{F}$ for their parsimony and explanatory power would be the basis for public policy in BF in Colombia.

\section{On economic inequality}

The analysis of the set of indices allows a reasonable conclusion regarding the existence or nonexistence of economic inequality, in this case in the duration of EBF and $\mathrm{BF}$. The economic inequality in the duration of EBF and $\mathrm{BF}$ in Colombia, in relative terms, is greater for EBF. However, in general terms, for both EBF and BF, inequality is nonexistent or is low. The different indices calculated for EBF are in the range of nonexistence of inequality or are acceptable. This finding is consistent with a study of other variables of interest for nutrition in Colombia, such as time in front of screens (excess of watching television or playing video game) and adds evidence to the breach of the basic paradigm in the study of economic inequalities in health, i.e., "the poor are in a worse condition than the most privileged"13. In Colombia, at an ecological level and based on the median duration of EBF and BF, both poor and privileged territory are below what is recommended by the WHO as acceptable for the duration of BF. The nonexistence of economic inequality contradicts evidence at the individual level shown in other countries ${ }^{7,10,29}$. However, the results are not comparable since the cultural, social and economic contexts are different. The failure to meet the duration goals recommended by the WHO is a trend worldwide ${ }^{32}$.

\section{About social determinants}

The gender empowerment measure as a proxy of woman's formal inclusion in the work environment is the most determinant variable of EBF and BF. When women's empowerment is greater, poverty is lower and their ability to determine themselves is greater. Therefore, while poverty in the territory is directly related to $\mathrm{BF}$, empowerment is negatively related. An inverse relationship of employment with BF and duration has been consistently reported in various societies and studies ${ }^{9,10}$. Several solutions have been proposed, such as approving paid $\mathrm{BF}$ licenses ${ }^{33,34}$, maintaining daycare centers incorporated in large industries, establishing insurance policies to meet the medical care related to $\mathrm{BF}^{35}$, giving women break time to breastfeed during the workday, and creating BF-friendly environments in public places ${ }^{36}$. However, it is consistently reported that returning to work marks the end of BF; therefore, the search for viable alternatives for women, the work environment and the finance of the state remains. GEM is a variable that despite being formally limited by the indicator of UNDP to three dimensions encompasses many more. GEM is transversal to other dimensions and should be understood as the ability to decide in many other aspects. In turn it would be desirable that future studies explored new ways of approaching the concept of GEM.

The inverse relationship between medical coverage (\%) and EBF shows that a higher care supply does not translate into quality. The duration of $\mathrm{BF}$ is multicausal and is linked to specific healthcare interventions, such as prenatal care, postpartum counseling ${ }^{8}$, children's 
hospitals, prescription regulations and the supply of dairy formulas and substitutes ${ }^{14}$. Another explanation is that the relationship is not necessarily linear-in peripheral coverage (\%), the duration is shorter. At an ecological level, the same medical coverage does not always represent the same medical care. The best infrastructure, more specialties and subspecialties and the most qualified human resources for care are concentrated in the most developed territories.

$\mathrm{BF}$ and the rate of female abuse were associated in a positive way. The few studies that have explored this relationship are consistent and contradict this finding. Female abuse is associated with the termination of $\mathrm{BF}^{37}$, and women who report abuse have a $21 \%$ to $40 \%$ higher probability of abandoning BF than those who are not abused ${ }^{38}$. To explain this finding, as a hypothesis, it can be argued that in Colombia, in the territories with the most abused women, they look for affective compensation in their babies, resulting in increased BF within this cultural context. It is worth deepening this finding in future studies, as the effects of this type of traumatic relationship, added to $\mathrm{BF}$, surely affect the social integration of the mother and child.

As recommendations we declare, a) it is necessary to continue working from public policy to effectively incorporate the actions aimed at increasing the duration of BF and EBF, b) monetary poverty, but in general any form of exclusion and inequality affects the duration of BF; therefore, pregnant and lactating women in poverty and inequality must be declared as a new highly vulnerable group and subject to specific public policies, c) any form of violence against women and even more against lactating women should be eradicated, d) it is necessary to continue deepening on what is reported here as a novel finding: what happens in the medium and long term behavior of children who strengthen their bond with the mother product of abuse? What are the coping mechanisms for BF women against abuse? How to formulate a multilevel public policy that incorporates the findings reported here? The answers to these questions are beyond the scope of this study.

Finally, social and human development is the consequence of other types of developments and, therefore, strategies to increase the duration of both exclusive and total breastfeeding based on the woman or the mother-child binomial (High-risk approach, according to $\operatorname{Rose}^{39,40}$ ), they will be less cost-effective and cost-efficient, than the strategies based on general well-being. In short, to improve the structures that determine a higher quality of life in the population.

\section{Scope and limitations of the study}

The main risk when interpreting the results of an ecological study is the ecological fallacy or the application of the results at the individual level and not in the unit of analysis that gives rise to them, which in this study was the geodemographic unit. On the other hand, the limited sample size in ecological studies increases the probability of making type II errors ${ }^{19,41,42}$. Different types of studies can produce different results. Eg, cross-sectional studies such as the ENSIN look for the prevalence and duration of breastfeeding, casecontrol studies look for differences that are associated with prevalence and duration at the individual level, in cohort studies the density- incidence of exposures associated with the duration of lactation, in multilevel studies the objective is to establish the determinants of prevalence and duration at different levels (individuals, households, neighborhoods, region). This study seeks to identify the effects of macro determinants on population effects. For this reason, the results are not necessarily comparable with those obtained in a multi-level study, where effects would be obtained at the individual level of the macro determinants, nor are they inferior; simply different, but are of special importance for decisionmaking and public policy

The main strength of this study is that official data were used, which were provided by the best existing metrics, such as national surveys that have national representation and standardized systematic processes. Additional strengths were the ecological study design and the methodology used, which incorporated the effect of the territory (geodemographic units) to explain the duration of EBF and BF. Ecological studies incorporate aspects of the environment into the analysis using proximal variables, allowing the incorporation of interactions that are difficult to observe at the individual level. Another strength is the consistency with other studies in terms of the GEM results (employment) and the finding of a new variable-The abused women rate in the territory - to explain the duration of BF. The main limitation of this study is its inability to establish causality. Finalilly and as here in an ecological design, the results are determined by the differences in the prevalence and duration of breastfeeding between regions. These differences represent different stages of social, human and economic development.

\section{Ethical considerations}

Ethics approval and consent to participate. Each analysis was conducted under the principles of the Helsinki declaration. The sources used are public and are 
therefore unidentified. This study is classified as "riskfree" according to resolution 8430 of 1993, MinSalud, Colombia. The medical research ethics committee of the National University of Colombia (Universidad Nacional de Colombia) approved all procedures.

Consent for publication. Not applicable

Availability of data and material. All data analyzed during this study for the ecological level and for the individual level during the current study are not publicly available as they belong to the ICBF, Colombia, but are available from the corresponding author upon reasonable request.

\section{Conflict of interests}

The authors do not have any conflict of interest or significant potential, to declare.

\section{References}

1. Binns C, Lee M, Low WY. The long-term public health benefits of breastfeeding. Asia Pac J Public Health. 2016; 28(1): 7-14. doi: https://doi. org/10.1177/1010539515624964

2. Collazo CR, Hérnadez-Rodríguez Y, AndradeCampoverde D. Breastfeeding, metabolic programming and its relationship with chronic diseases. Salu Uninorte. 2018; 34(1): 126-143. doi: http://dx.doi.org/10.14482/sun.34.1.8923

3. Colchero MA, Contreras-Loya D, Lopez-Gatell $\mathrm{H}$, Gonzalez de Cosio T. The costs of inadequate breastfeeding of infants in Mexico. Am J Clin Nutr. 2015;101(3): 579-586. doi: https//doi:10.3945/ ajcn.114.092775

4. Balogun OO, O'Sullivan EJ, McFadden A, Ota $\mathrm{E}$, Gavine A, Garner $\mathrm{CD}$, et al. Interventions for promoting the initiation of breastfeeding. Cochrane Database Syst Rev. 2016;11: CD001688. doi: https://doi.org/10.1002/14651858.CD001688.pub3

5. Smith LA, Geller NL, Kellams AL, Colson ER, Rybin DV, Heeren T, et al. Infant sleep location and breastfeeding practices in the United States, 2011-2014. Acad Pediatr. 2016; 16(6): 540-549. doi: https://doi.org/10.1016/j.acap.2016.01.021

6. Dunn RL, Kalich KA, Fedrizzi R, Phillips S. Barriers and contributors to breastfeeding in WIC mothers: A social ecological perspective. Breastfeed Med. 2015; 10(10): 493-501. doi: https://doi.org/10.1089/ bfm.2015.0084

7. Ahluwalia IB, Morrow B, D'Angelo D, Li R. Maternity care practices and breastfeeding experiences of women in different racial and ethnic groups: Pregnancy risk assessment and monitoring system (PRAMS). Matern Child Health J. 2012; 16(8): 1672-1678. doi: https://doi.org/10.1007/ s10995-011-0871-0

8. Bueno-Gutierrez D, Chantry C. Life does not make it easy to breast-feed: Using the socio-ecological framework to determine social breast-feeding obstacles in a low-income population in Tijuana, Mexico. Breastfeed Med. 2015; 10(2): 124-131. doi: https://doi.org/10.1089/bfm.2014.0109

9. Bai DL, Fong DYT, Tarrant M. Factors associated with breastfeeding duration and exclusivity in mothers returning to paid employment postpartum. Matern Child Health J. 2015; 19(5): 990-999. doi: https://doi.org/10.1007/s10995-014-1596-7

10. Amir LH, Donath SM. Socioeconomic status and rates of breastfeeding in Australia: Evidence from three recent national health surveys. Med J Aust. 2008; 189(5): 254-256.

11. Diez-Roux AV. Investigating neighborhood and area effects on health. Am J Public Health. 2001; 91(11): 1783-1789.

12. Wiese D, Stroup AM, Maiti A, Harris G, Lynch SM, Vucetic V et al. Measuring Neighborhood Landscapes: Associations between a neighborhood's landscape characteristics and colon cancer survival. Int J Environ Res Public Health. 2021; 18(9): 4728. doi: https://doi.org/10.3390/ijerph18094728

13. Herrán OF, Patiño GA, DelCastillo SE. Desigualdad y nutrición: Encuesta de la situación nutricional en Colombia, 2010. Rev Bras Saude Mater Infant. 2015; 15(4): 401-412. doi: https://doi.org/10.1590/ S1519-38292015000400004

14. Ministerio de la Protección Social., Instituto Colombiano de Bienestar Familiar, \& Instituto Nacional de Salud. Encuesta nacional de la situación nutricional en Colombia 2010. Ensin, 2011; 1-512. https://www.icbf.gov.co/bienestar/nutricion/ encuesta-nacional-situacion-nutricional

15. Instituto de Medicina Legal y Ciencias Forences. Obsertorio de Violencia Contra la Mujer, Colombia. https://www.medicinalegal.gov.co/observatorio-deviolencia-contra-la-mujer

16. Sierra-Gómez CT. Violencia contra la mujer en Colombia: Reflexiones sobre los mecanismos para su protección. https://repository.ucatolica.edu.co/ bitstream/10983/20582/1/Articulo\%20Tatiana\%20 Sierra\%20PDF.pdf

17. Martin-de-Las-Heras S, Velasco C, Luna-DelCastillo JD, Khan KS. Breastfeeding avoidance following psychological intimate partner violence during pregnancy: a cohort study and 
multivariate analysis. BJOG. 2019; 126(6): 778783. doi: https://doi.org/10.1111/1471-0528.15592

18. DANE (Departamento Administrativo Nacional de Estadística). Pobreza y desigualdad - 2011. 2011; https://www.dane.gov.co/index.php/estadisticaspor-tema/pobreza-y-condiciones-de-vida/ pobreza-y-desigualdad/pobreza-y-desigualdad2011\#pobreza-monetaria-por-departamentos-2011

19. Morgenstern H. Ecologic studies in epidemiology: concepts, principles, and methods. Annu Rev Public Health. 1995; 16:61-61.https://www.annualreviews. org/doi/pdf/10.1146/annurev.pu.16.050195.000425

20. DANE (Departamento Administrativo Nacional de Estadística). Proyecciones de población, Colombia 2005-2020. 2005; https://www.dane.gov.co/index. php/estadisticas-por-tema/demografia-y-poblacion/ proyecciones-de-poblacion

21. DANE (Departamento Administrativo Nacional de Estadística). Nacimientos 2010. Colombia, 2010; https://www.dane.gov.co/index.php/estadisticaspor-tema/salud/nacimientos-y-defunciones/ nacimientos/nacimientos-2010

22. DANE (Departamento Administrativo Nacional de Estadística). Cifras departamentales de pobreza monetaria y desigualdad, 2012. https:/www.dane. gov.co/index.php/estadisticas-por-tema/pobrezay-condiciones-de-vida/pobreza-y-desigualdad/ pobreza-y-desigualdad-2012

23. Mancero X. Revisión de algunos indicadores para medir la desigualdad. In Sexto taller regional sobre indicadores sobre el desarrollo social. Buenos Aires: CEPAL, 2000. LC/R.2046 - 2000. pp. 375-386

24. DANE (Departamento Administrativo Nacional de Estadística). Cuentas departamentales - Colombia producto interno bruto (PIB) comportamiento 2000-2012. 2014; https://www.dane.gov.co/files/ investigaciones/pib/departamentales/B_2005/Bol_ dptal_2011def_2012pre.pdf

25. UNPD. Informe Nacional de Desarrollo Humano. Colombia rural razones para la esperanza, 2011. http://hdr.undp.org/sites/default/files/nhdr_ colombia_2011_es_low.pdf

26. DANE (Departamento Administrativo Nacional de Estadística). Gran encuesta integrada de hogares -GEIH- históricos, 2011. https://www.dane.gov.co/ index.php/estadisticas-por-tema/mercado-laboral/ empleo-y-desempleo/geih-historicos

27. Lorena V, Bernal V, Mancera NL. Comportamiento de la violencia intrafamiliar, Colombia, 2012. Bogotá, DC: Instituto de Medicina Legal, Colombia.

28. Minsalud. Situación de salud en Colombia 2012. https://www.minsalud.gov.co/sites/rid/Lists/ BibliotecaDigital/RIDE/VS/ED/PSP/Indicadores- basicos-en-salud-2012.pdf

29. Consellería de Sanidade, Xunta de Galicia, España, Organización Panamericana de la Salud, Universidad CES. Epidat: Programa para análisis epidemiológico de datos, 2016. http://www.sergas. es/Saude-publica/EPIDAT

30. StataCorp. (2015). Stata statistical software: Release 14.1 College Station, TX: StataCorp LP.

31. Banco Mundial. https://datos.bancomundial.org/ indicador/SI.POV.GINI?locations $=\mathrm{CA}$

32. Asociación Española de Pediatría: Comité de Lactancia Materna. Lactancia materna en cifras: Tasa de inicio y duración de la lactancia materna en España y otros paises. Madrid, 2016. https://www. aeped.es/sites/default/files/documentos/201602lactancia-materna-cifras.pdf

33. Huang R, Yang M. Paid maternity leave and breastfeeding practice before and after California's implementation of the nation's first paid family leave program. Eco Hum Biol. 2015;16: 45-59. doi: https://doi.org/10.1016/j.ehb.2013.12.009

34. Mirkovic KR, Perrine CG, Scanlon KS. Paid maternity leave and breastfeeding outcomes. Birth. 2016:43(3): 233-239. doi: https://doi.org/10.1111/ birt. 12230

35. Madden S, Curtis B. The case for creating a model insurance policy: Payer coverage of breastfeeding counseling services, pumps, and supplies. Breastfeed Med. 2013; 8(5): 450-452. doi: https:// doi.org/10.1089/bfm.2013.0078

36. Bettinelli ME. Breastfeeding policies and breastfeeding support programs in the mother's workplace. J Matern Fetal Neonatal Med. 2012;25(Sup4): 73-74. https://doi.org/10.3109/147 67058.2012.715033

37. Moraes CL, de Oliveira ASD, Reichenheim ME, Lobato G. Severe physical violence between intimate partners during pregnancy: A risk factor for early cessation of exclusive breast-feeding. Public Health Nutr. 2011; 14(12): 2148-2155. doi: https:// doi.org/10.1017/S1368980011000802

38. Sørbø MF, Lukasse M, Brantsæter A, Grimstad H. Past and recent abuse is associated with early cessation of breast feeding: Results from a large prospective cohort in Norway. BMJ Open. 2015;5(12): 9240. doi: https://doi.org/10.1136/ bmjopen-2015-009240

39. Rose G. Estratégias da medicina preventiva. Porto Alegre: Artmed; 2010. 192 p.

40. Norman AH, Estratégias da medicina preventiva de Geoffrey Rose. Rev Bras Med Fam Comunidade. 2015;10(34): 1-3. doi: https://doi.org/10.5712/ rbmfc10(34)1092 
41. Idrovo J. Three criteria for ecological falacy. Environ Health Perspect. 2011;119(8): a332. doi: https://doi.org/10.1289/ehp.1103768

42. Blanco-Becerra LC, Pinzón-Flórez CE, Idrovo AJ. Estudios ecológicos en salud ambiental: más allá de la epidemiología. Biomédica. 2015; 35(Supl.2): 191-206. doi: https://doi.org/10.7705/biomedica. v35i0.2819 